\title{
PRELIMINARY RESEARCH ON SOME MORPHOMETRIC CHARACTERISTICS OF EUROPEAN RED WOOD ANTS (FORMICA PRATENSIS RETZIUS, 1783) ALONG THE TURKEY- BULGARIA CROSS-BORDER AREA
}

\author{
Y1lmaz ÇAMLITEPE ${ }^{1 *}(\mathbb{D})$, Volkan AKSOY ${ }^{1}$ D , Albena LAPEVA-GJONOVA ${ }^{2}$, \\ Kaan YENCE $^{1}$ D, Cansu DUMLU ${ }^{3}$, Ilia GJONOV ${ }^{2}$ \\ ${ }^{I}$ Trakya University, Faculty of Sciences, Department of Biology, Balkan Campus, Edirne, Turkey \\ ${ }^{2}$ Sofia University "Sv. Kliment Ohridski" Department of Zoology and Anthropology, 8 Dragan Tzankov blvd., Sofia, \\ Bulgaria \\ ${ }^{3}$ Trakya University, Institute of Natural and Applied Sciences, Balkan Campus, Edirne, Turkey
}

\begin{abstract}
Formica pratensis Retzius, 1783 (Hymenoptera: Formicidae) is one of the members of the wood ants group and is represented in Europe with the hairy $\mathrm{N}$ morph common in the south and the less hairy $\mathrm{P}$ morph common in the north. The species is naturally distributed in European part of Turkey (Thrace Region) and in the neighboring parts of Bulgaria. Former studies of Bernhard Seifert showed that the $\mathrm{N}$ morph is the dominant morph in south Bulgaria, but the situation in Turkey is not known. In the present study, we sampled workers from some colonies of $F$. pratensis in Turkey and Bulgaria and obtained a pilosity data for each colony in the two countries. The comparison of our data with that of Seifert showed that the Bulgaria samples well fit with the pilosity data of $\mathrm{P}$ morph and Turkey samples were apparently less hairy but hairs are longer than all other populations. The results helped us to show that $F$. pratensis can have ecomorphological traits other than that fitting the definition of $\mathrm{N}$ and $\mathrm{P}$ morphs and that traits may differ from one to another population distributed even along in a small scale of area.
\end{abstract}

Keywords: Formica pratensis, Pilosity, Ecomorphology, European Red Wood Ant 


\section{TÜRKIYYE-BULGARISTAN SINIR BÖLGESINDEKİ AVRUPA KIRMIZI ORMAN KARINCASININ (FORMICA PRATENSIS RETZIUS, 1783) MORFOMETRÍK KARAKTERLERİ ÜZERİNE BİR ÖN ÇALIŞMA}

$\ddot{O} \mathbf{z}$

Formica pratensis Retzius, 1783 (Hymenoptera: Formicidae) orman karıncaları grubunun bir üyesidir ve Avrupa'da güneyde daha yaygın olan kıllı N morf ile kuzeyde daha yaygın olan daha az kıllı P morf ile temsil edilmektedir. Tür Türkiye'de Trakya Bölgesinde ve Bulgaristan'in bu bölgeye komşu sınır alanlarında doğal olarak yayılış göstermektedir. Bernhard Seifert'in daha önceki çalışmaları güney Bulgaristan'da türün $\mathrm{N}$ morfunun baskın olduğunu göstermişken Türkiye'deki durumu bilinmemektedir. Bu çalışmada Türkiye ve Bulgaristan'dan bazı F. pratensis kolonilerinden işçi sınıfına giren karıncalar örneklenmiş ve her iki ülke örnekleri için bir kıllılık veri seti oluşturulmuştur. Elde edilen veri setinin Seifert'in bulguları ile karşılaştırılması Bulgaristan'daki örneklerin P morf ile uyuştuğunu, Türkiye örneklerinin ise belirgin şekilde daha az k1llı olduğunu ancak bu kılların diğer tüm popülasyonlardakinden daha uzun olduğunu göstermiştir. Sonuçlar $F$. pratensis'in $\mathrm{N}$ ve $\mathrm{P}$ morf tanımlarına uyanlar dışında ekomorfolojik özelliklere sahip olabileceğini ve bu özelliklerin çok dar bir alanda dağılım gösteren popülasyonlar arasında dahi farklılık gösterebileceğini göstermemize olanak tanımıştır.

Anahtar kelimeler: Formica pratensis, K1ll11ık, Ekomorfoloji, Avrupa Kırmızı Orman Karıncası

\section{Introduction}

In his referred publication on lizard evolution in an island fauna, Williams (1972) defined the term ecomorph as "species with the same structural habitat/niche, similar in morphology and behavior, but not necessarily close phyletically" [1]. The term was covered in many studies on various invertebrate taxa and is used as an equivalent of ecological specialist in recent uses [2-5]. A number of ant traits such as femur length, eye size and overall body size [6-8] are known to be correlated with the ecological niche in a given habitat [9]. Thus, the trait morphology is a useful tool to predict ecology and can be used to define ant ecomorphs. For instance, the ant genus Strumigenys is characterized with two main ecomorphs as short-mandibled and long-mandibled forms, the former employing a strategy of luring or cautiously approaching prey and the latter hunting as more active hunters using the trap-jaw mechanism of their mandibles [10]. Seifert reported a climate based 
adaptation for ecomorphs of the ant Lasius japonicus Santschi, 1941 in which darker forms, in terms of body coloration, were reported to be slightly smaller with longer heads possibly representing the ecomorph adapted to cooler climates [11]. Although researchers are suggested to approach with suspicion for such cases considering the possibility of polymorphism of one species or the existence of highly similar siblings, the ecomorph phenomenon may be a reliable tool to solve some taxonomic controversies as in the case of Formica nigricans Emery, 1909.

Following the description of Formica rufa pratensis var. nigricans by Carlo Emery in 1909, myrmecologists adopted two opposing views. Kutter and later Collingwood argued that it was a separate species [12-13] and Dlusskii and Paraschivescu refused this separation [14-15]. Seifert sampled specimens of Formica pratensis Retzius, 1783 from all over Europe and decided, based particularly on pilocity data, that nigricans was in fact a hairy morph of $F$. pratensis which he thought to have differing ecological adaptations [11]. The hairy morph was termed as $\mathrm{N}$ morph and the less hairy as $\mathrm{P}$ morph. The data of Seifert showed that $\mathrm{N}$ morph was more common in the south and the $\mathrm{P}$ morph was more common in the north of Europe, although both could be found as sympatric populations. In Turkey, F. pratensis is naturally distributed only in European part of the country (the Thrace Region) and is represented with colonies in low numbers particularly throughout the northern parts of the region. It is also present in the neighboring Bulgaria, also in low numbers [16-18]. Studies over the last the decade showed that the species is in Vulnerable (VU) status in its distribution area in Turkey and most probably in Bulgaria [19-21]. Studies also showed that most of the colonies were established in open forest areas, some under relatively dense forest cover and a few in open field areas with increased sun exposure. Following our preliminary observations on some morphological traits on colony level in laboratory and on ecological preferences in the field in both countries, we predicted that the species may have local morphological adaptations. In order to test our prediction, we sampled colonies during a field study in the transborder areas of Turkey and Bulgaria and produced a comparable data set on some morphological traits of workers about pilosity. The results helped us to show that $F$. pratensis can have ecomorphological traits other than that fitting the definition of $\mathrm{N}$ and $\mathrm{P}$ morphs and that traits may differ from one to another population distributed even along in a small scale of area.

Preliminary Research On Some Morphometric Characteristics Of European Red Wood Ants (Formica Pratensis Retzius, 1783) Along The 


\section{Materials and Methods}

The field studies were performed in the transborder areas of Turkey and Bulgaria where $F$. pratensis colonies are distributed. 29 nests in 9 localities in Turkish Thrace and 8 nests in 3 localities in Bulgaria were visited (Figure 1). For each nest, 30 workers were sampled randomly, put in $70 \%$ ethanol containing tubes and brought to the laboratory for further analysis. Each specimen was mounted on a special triangle label following standard mounting procedures used for ants. The morphological characters used by Seifert for the worker caste were considered in the study. For this purpose, maximum measurable head width (HW), number of standing hairs on one half of occipital margin frontad to eye level and seen in straight dorsal view (NBH), length of the longest hair on occipital margin of head seen in straight dorsal view (LBH) and number of standing hairs on extensor profile of hind tibia (NHTI) were measured and counted for each specimen under a stereomicroscope (Olympus brand) with $30 \times 10$ magnification. The mean values of each data were measured and a comparative analysis with that reported by Seifert for $\mathrm{N}$ and $\mathrm{P}$ morphs in Europe was performed.

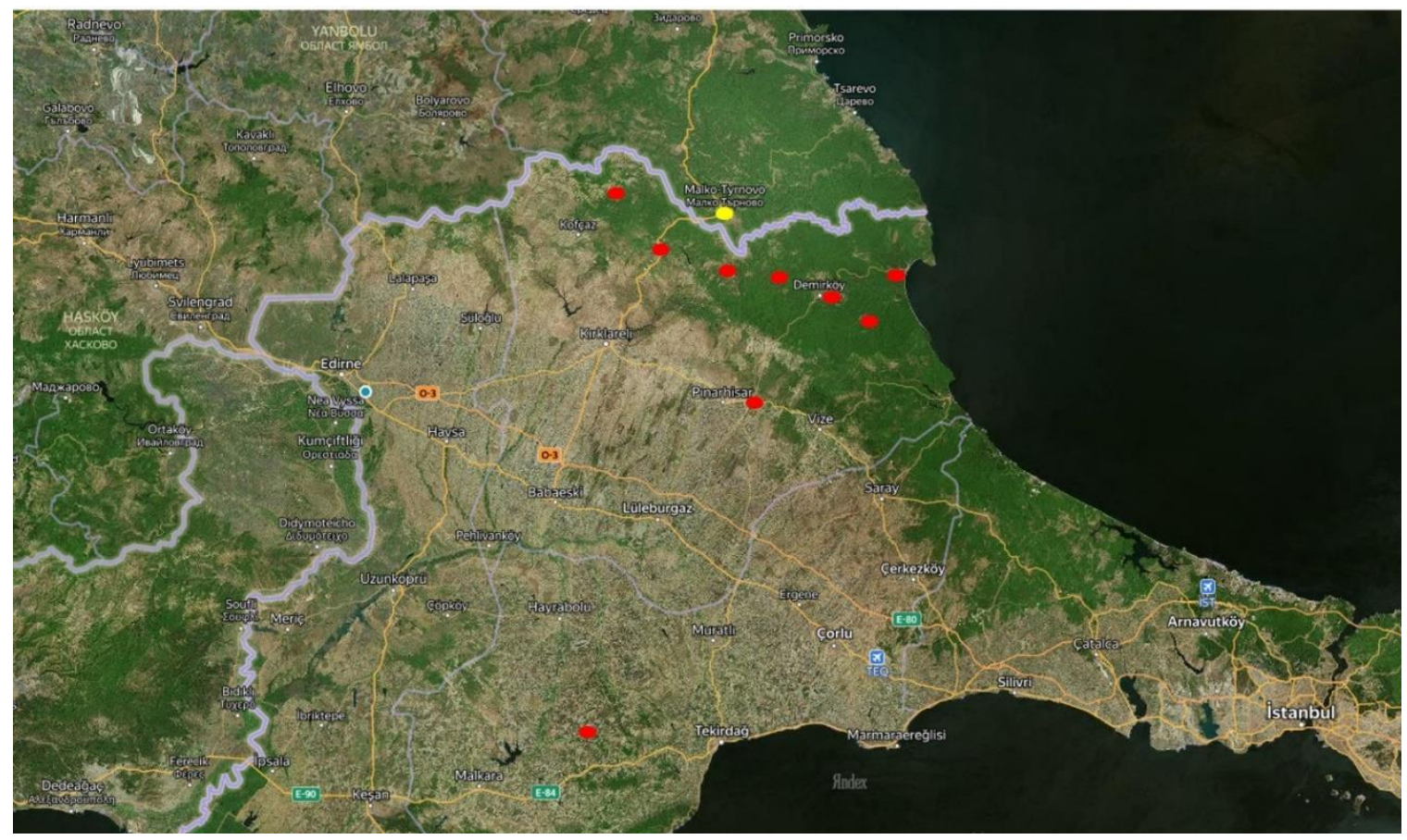

Figure 1. Map showing the localities where $F$. pratensis workers were sampled in Turkey (solid red circles) and Bulgaria (solid yellow circle). 


\section{Results and Discussion}

The results of measurements for Turkish and Bulgarian $F$. pratensis samples are given in Table 1 and the comparison of pilosity data (based on NBH and LBH) is given in Figure 2.

Table 1. The measured morphological traits of $F$. pratensis workers are given with mean $\pm \mathrm{SD}$ values. Data reported by Seifert (1992) were also included in the table for comparison. HW and LBH values are in $\mathrm{mm}$.

\begin{tabular}{|c|c|c|c|c|}
\hline & $\begin{array}{c}\text { Turkish Samples } \\
(\mathbf{n}=\mathbf{8 7 0})\end{array}$ & $\begin{array}{c}\text { Bulgarian Samples } \\
(\mathbf{n = 2 4 0})\end{array}$ & $\begin{array}{c}\text { N Morph } \\
(\text { Seifert, 1992) } \\
(\mathbf{n = 7 9 4 )}\end{array}$ & $\begin{array}{c}\text { P Morph } \\
(\text { Seifert, 1992) } \\
(\mathbf{n = 9 6 2})\end{array}$ \\
\hline HW & $1.94 \pm 0.14$ & $1,69 \pm 0.117$ & $1.77 \pm 0.21$ & $1.81 \pm 0.21$ \\
\hline NBH & $12.51 \pm 2.64$ & $21.33 \pm 2.82$ & $28.17 \pm 6.42$ & $17.87 \pm 5.74$ \\
\hline LBH & $0.229 \pm 0.08$ & $0.13 \pm 0.02$ & $0.14 \pm 0.02$ & $0.109 \pm 0.026$ \\
\hline NHTI & $18.03 \pm 2.34$ & $15.87 \pm 3.29$ & $25.12 \pm 5.11$ & $17.83 \pm 5.21$ \\
\hline
\end{tabular}

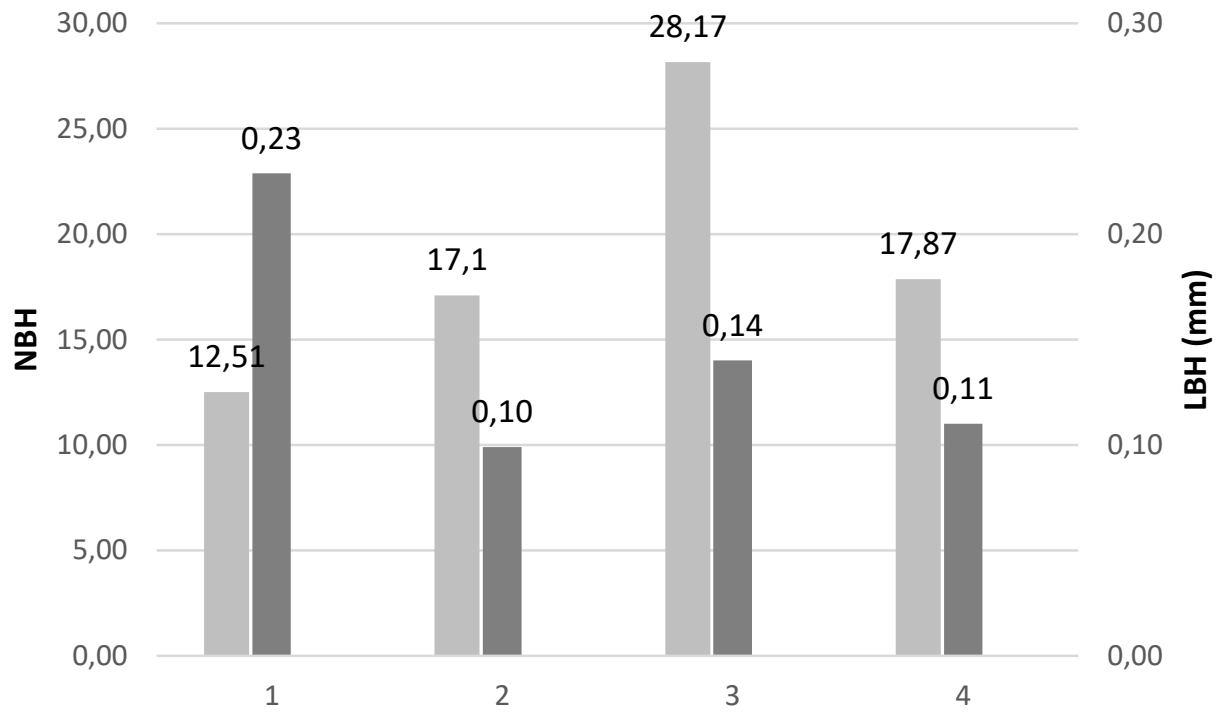

Figure 2. NBH and LBH values of 1) Turkish and 2) Bulgarian specimens and 3) $\mathrm{N}$ and 4) $\mathrm{P}$ morphs reported by Seifert (1992). Light gray bars correspond to NBH and dark gray bars correspond to LBH values. All values are given in $\mathrm{mm}$.

It is clear from the comparison graph that Bulgarian $F$. pratensis well fits with the pilosity data of $\mathrm{P}$ morph. Interestingly, Seifert reported that the $\mathrm{N}$ morph dominates $\mathrm{P}$ morph in south Bulgaria 
with a 5:1 ratio [11]. On the other hand, although we may expect considerable intraspecific variability of individuals of colonies of wood ants [22], the pilocity data of Turkish population is striking. The workers of Turkish colonies are apparently less hairy, at least in terms of standing hairs on one half of occipital margin of the head, but the length of these hairs are longer not only than workers in Bulgarian colonies but also from mean data reported for $\mathrm{N}$ and $\mathrm{P}$ morphs in Europe. Although Seifert defined significant differences between the two morphs based on body size, pilosity, geographic frequency, habitat selection and mound characteristics, the difference of morphometric data of Turkish $F$. pratensis in comparison with others cannot be conveniently explained with one or more of these characteristics. The mounds of the colonies in both countries were typical for the species, the habitats where the colonies were found did not differ from each other in most habitat features. Morphological traits are directly related to the interaction of a species with its environment [23] and a number of functions, including defense against predation, prevention of water immersion, desiccation tolerance and thermoregulation were hypothesized for pilosity related traits [24]. We conclude that being less hairy may not be an adaptive character for workers particularly in terms of sun exposure but is compensated with an increase in hair length which might have taken over the UV protection role of dense hairs. Hairiness, in addition to some other traits in red wood ants might be useful traits for monitoring habitat degradation. For instance, Fedoseeva reported for Formica aquilonia ants collected in 1969-1992 from two settlements in Solnechnogorsk Forestry in Moscow that workers from the two settlements differed from each other in terms of size and pilosity [25]. Comparison of workers covering three generations from a single settlement revealed that a significant pilosity increase occurred coinciding with settlement degradation after mass destruction of ant nests by various animals. A more strong explanation with more powerful evidence is expected with further studies in both Turkey and Bulgaria which may be planned for consecutive seasons for the same colonies to see if any change will occur in pilosity data. Such a long term study will also help us to better understand whether the different pilosity pattern in Turkish $F$. pratensis population is an ecomorphological adaptation or response, either long lasting or short-term, to environmental features or stress factors.

Preliminary Research On Some Morphometric Characteristics Of European Red Wood Ants (Formica Pratensis Retzius, 1783) Along The 


\section{Acknowledgements}

This study was financially supported by the project CB005.2.12. 012 "Joint initiatives for the conservation of zonal European red wood ants facing the danger of extinction", INTERREG - IPA CBC BULGARIA - TURKEY PROGRAMME 2014-2020 CCI NO 2014TC16I5CB005.

\section{REFERENCES}

[1] Williams, E. E. The origin of faunas. Evolution of lizard congeners in a complex island fauna: a trial analysis. In Evolutionary biology (pp. 47-89). Springer, New York, 1972.

[2] Brady, S. G., Schultz, T. R., Fisher, B. L., Ward, P. S., Evaluating alternative hypotheses for the early evolution and diversification of ants. Proceedings of the National Academy of Sciences, C 103(48), S 18172-18177, 2006.

[3] Branstetter, M. G., Revision of the Middle American clade of the ant genus Stenamma Westwood (Hymenoptera, Formicidae, Myrmicinae). ZooKeys, C 295, 1, 2013.

[4] Gillespie, R., Community assembly through adaptive radiation in Hawaiian spiders. Science, C 303(5656), S 356-359, 2004.

[5] Gillespie, R. G., Benjamin, S. P., Brewer, M. S., Rivera, M. A. J., Roderick, G. K., Repeated diversification of ecomorphs in Hawaiian stick spiders. Current Biology, C 28(6), S 941-947, 2018.

[6] Gibb, H., Stoklosa, J., Warton, D. I., Brown, A. M., Andrew, N. R., Cunningham, S. A., Does morphology predict trophic position and habitat use of ant species and assemblages?. Oecologia, C 177(2), S 519-531, 2015.

[7] Guilherme, D. R., Souza, J. L. P., Franklin, E., Pequeno, P. A. C. L., das Chagas, A. C., Baccaro, F. B., Can environmental complexity predict functional trait composition of ground-dwelling ant assemblages? A test across the Amazon Basin. Acta Oecologica, C 99, S 103434, 2019.

[8] Weiser, M. D., Kaspari, M., Ecological morphospace of New World ants. Ecological Entomology, C 31, S 131-142, 2006.

[9] Sosiak, C. E., Barden, P., Multidimensional trait morphology predicts ecology across ant lineages. Functional Ecology, C 35(1), S 139-152, 2021.

[10] Brown Jr, W. L., Wilson, E. O., The evolution of the dacetine ants. The Quarterly Review of Biology, C 34(4), S 278-294, 1959.

Preliminary Research On Some Morphometric Characteristics Of European Red Wood Ants (Formica Pratensis Retzius, 1783) Along The 
[11] Seifert, B., Formica nigricans EMERY, 1909-an ecomorph of Formica pratensis RETZIUS, 1783 (Hymenoptera, Formicidae). Entomologica Fennica, C 2(4), S 217-226, 1992.

[12] Kutter, H., Hymenoptera - Formicidae. - Fauna Insecta Helvetica 6. Zurich, 1977.

[13] Collingwood, C. A., The Formicidae of Fennoscandia and Denmark. - Fauna Entomol. Scandinavica 8. Klampenborg, 1979.

[14] Dlusskii , G., Ants of the genus Formica. (In Russian) - Izd. Nauka, Moscow, 1967.

[15] Paraschievescu, D., Pozitia sistematica a speciilor Formica pratensis Retz. si F. nigricans Emery.- Stud. Cercet. Bioi. Seria Zoologie, C 24(6), S 527-535, 1972.

[16] Antonova, V., Marinov, M. P., Red wood ants in Bulgaria: distribution and density related to habitat characteristics. Journal of Hymenoptera Research, C 85, S 135, 2021.

[17] Lapeva-Gjonova, A., Antonova, V., Radchenko, A., Atanasova, M., Catalogue of the ants (Hymenoptera: Formicidae) of Bulgaria. ZooKeys, C 62, S 1-124, 2010.

[18] Lapeva-Gjonova, A., Antonova, V., Ljubomirov, T., Ants (Hymenoptera, Formicidae) ofSarnena Sredna Gora Mountains (Bulgaria). In: Georgiev D, Bechev D, Yancheva V (Eds) Fauna of Sarnena Sredna Gora Mts, Part 2, Zoonotes, Supplement 10: 18-27, 2021.

[19] Çamlitepe, Y., Aksoy, V., Distribution and Conservation Status of the European Red Wood Ant Species Formica pratensis Retzius, 1783 (Hymenoptera, Formicidae) in (European) Turkey. Journal of the Entomological Research Society, C 21(2), S 199-211, 2019.

[20] Kiran, K., Karaman, C., First annotated checklist of the ant fauna of Turkey (Hymenoptera: Formicidae), Zootaxa, C 3548(1), S 1-38, 2012.

[21] Kiran, K., Karaman, C., Additions to the ant fauna of Turkey (Hymenoptera, Formicidae), Zoosystema, C 42, S 285-329, 2020.

[22] Czechowski, W., Radchenko, A., Do permanently mixed colonies of wood ants (Hymenoptera: Formicidae) really exist? Annales Zoologici, C 56(4), S 667-673, 2006.

[23] Yates, M. L., Andrew, N. R., Binns, M., Gibb, H., Morphological traits: Predictable responses to macrohabitats across a $300 \mathrm{~km}$ scale. PeerJ, 2, e271, 2014.

[24] Buxton, J. T., Robert, K. A., Marshall, A. T., Dutka, T. L., Gibb, H., A cross-species test of the function of cuticular traits in ants (Hymenoptera: Formicidae). Myrmecological News, C 31, S 31-46, 2021. 
[25] Fedoseeva, E. B., Morphometric characteristics of Formica aquilonia ants in monitoring of their settlements. Entomological Review, C 91(2), S 152-168, 2011. 